Management Dynamics

Vol. 23, No. 1: 85-92, 2020

Shanker Dev Campus

Doi: https://doi.org/10.3126/md.v23i1.35563

\title{
Service quality and customer satisfaction on two wheelers in Nepal
}

Mikha Shrestha *

Abstract

Service quality is a key to survival for all service providing companies. The modern customer is savoy and technology driven who is demanding better services. With better services companies ensure customer satisfaction which eventually leads to retention of customers. This study accesses to explore the relation between service quality variables and customer satisfaction on two wheelers in Nepal. For this purpose, descriptive cum analytical research design was been adopted. Total 200 Bajaj motorbike owners were taken as a sample. Primary data have been used in the study with the pre structured questionnaires. The findings from correlation matrix showed a significant and positive relationship between service quality and customer satisfaction while comparing dimensions like responsiveness, reliability, assurance, tangibility and empathy. This research resulted in the development of a valid and reliable scale for measuring service quality in the Bajaj two wheelers in Nepal.

Keywords: Marketing, Service quality, Customer Satisfaction, Two wheelers.

Paper Type: Research Paper.

\section{Introduction}

Customer satisfaction came as a result of service quality. In relating service quality and customer satisfaction, researchers have been more precise about the meaning and measurements of service quality and satisfaction. Service quality and satisfaction have certain things in common, but satisfaction generally is a broader concept, whereas service quality focuses specifically on dimensions of service (Wilson et al., 2008). The two wheelers industry has been growing rapidly over the year all over the world. The global market for two wheelers has shown tremendous growth over past decade. Asia has accounted for the vast majority of the growth, sales in the entire region growing more than three-fold over the past decade. Nepal is not an exception for that.

The dominance of motorcycles in the two wheelers industry is a common trend in most part of the world. The reason for this is product specific as well as general. The study focuses on the service quality and consumer satisfaction towards Bajaj motorcycle in Nepal. This study emphasized to analyze Bajaj brands of bikes in Nepal as it has been able to gain and retain their target customers and hold sufficient shares in the market. The study has been designed to answer the following research questions:

* Lecturer, Shanker Dev Campus mikha.shrestha@sdc.tu.edu.np 
- What is the level of service quality of Bajaj two wheelers in Nepal?

- What is the most influencing service quality variable on customer satisfaction of Bajaj two wheelers in Nepal?

- What is the relationship between service quality variables and customer satisfaction of Bajaj two wheelers in Nepal?

Based on the above research questions, this study intends to achieve the following research objectives:

- To measure the impact of service quality on customer satisfaction of Bajaj two wheelers in Nepal.

- To explore the most influencing service quality variables on customer satisfaction of Bajaj two wheelers in Nepal.

- To examine the relation between service quality variables and customer satisfaction of Bajaj two wheelers in Nepal.

\section{Literature review}

Khan and Jadoun (2015) conducted a study on "Evaluation of Service Quality in Two- Wheeler Automobile Industries Using Servqual Model" with the objective of determining how satisfied the customers are with the services being provided by these automobile industries. It is found that there is significant gap between customer expectation and perception in case of Hero and Honda whereas there is no significant gap found in Bajaj service industry.

Khanal (2016) conducted a study on "Analysis of service quality and increasing automobile market and its impact" with the objective of comparing the service quality of different two-wheeler automobile service industries. It is found that the users of personal vehicles hold higher expectations from service centers as the product is put to their personal use. The gap between expected and perceived service quality is considerable in case of automobile service centers for personal vehicles.

Ambekar (2017) conducted a study on "Service quality gap analysis of automobile service centers" with the main aim to find the gap between expected and perceived service quality factors in automobile service centers. This major objective is supported by the analysis of service quality factors for personal and commercial vehicle users.

Rimal (2018) conducted a study on "A Study on two wheelers consumers behaviour and consumer satisfaction" to examine the impact of selected independent variables on Customer Satisfaction. Study found moderate mean values for some dimensions. Hence suggested manufacturers/ dealers to invest highly valuable service staff in the specific problem areas, i.e., specialized skills, satisfaction after the test ride and quality of service.

Adusei and Koduah (2019) conducted a study on "After-Sales service and customer satisfaction in the automobile industry in an emerging economy" with the main aim to examine the role of 
after-sales services on customer satisfaction using CFAO Motors as a case study. The study concluded that CFAO Motor must be customer-centric organization through deployment of effective marketing strategies to build long term relationships with stakeholders to better its performance.

\section{Research gap}

Although few research have been conducted related to this topic but very few researchers talked about service quality and customer satisfaction on two wheelers in Nepal. However, service quality dimensions were frequently studied by the previous researchers, but service quality and customer satisfaction have been studied by only few researchers. This study consists of primary data that are acquired through the questionnaire method. To make the study more effective, the answers of the responses were analyzed. Hence the study helps to trace out the service quality and customer satisfaction of two wheelers in Nepal and fulfill the previous research gap.

\section{Research framework and definition of variables}

The SERVQUAL scale which is also known as the gap model by Parasuraman et al. (1988) has been proven to be one of the best ways to measure the quality of services provided to customers. This research has been emphasized to confirm service quality dimensions (SERVQUAL) like Tangibles (TAN), Reliability (REL), Responsiveness (RES), Assurance(ASS) and Empathy(EMP)was used to determine the overall service quality and customer satisfaction of the Bajaj two wheelers in Nepal to develop a conceptual model.

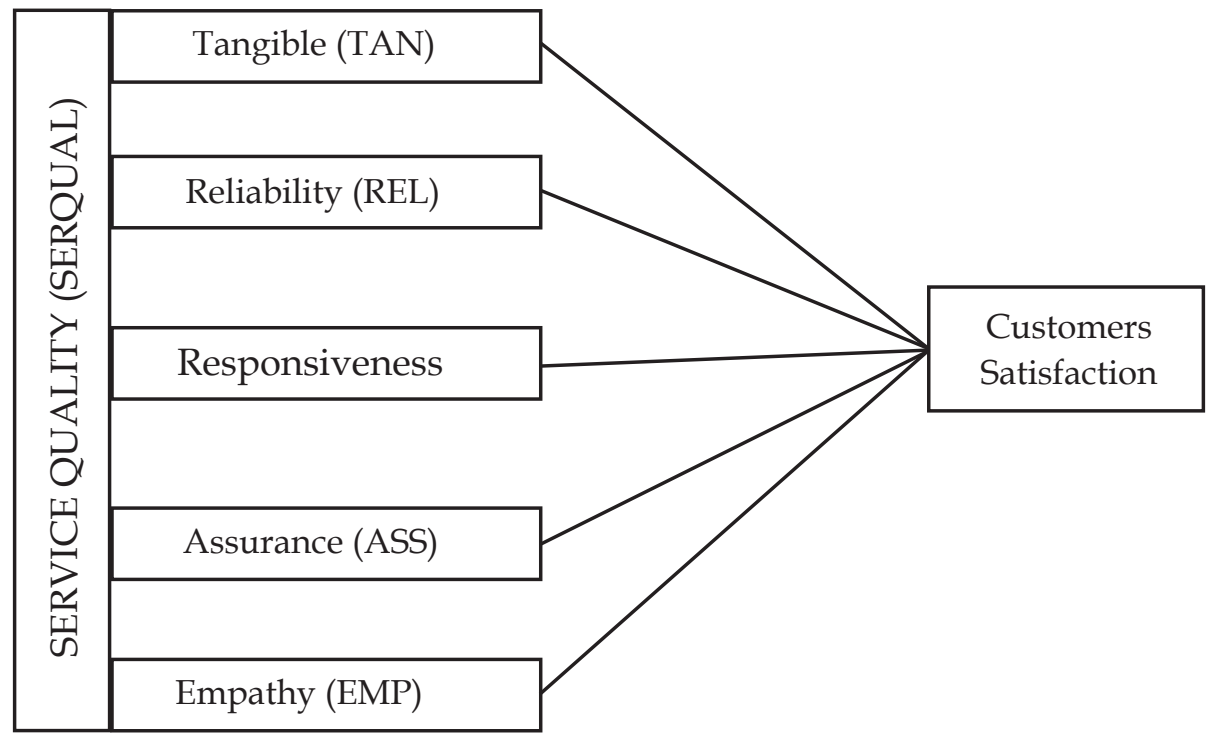

Figure 1: Research Framework

(Source: Parshuraman, et.al.; 1988) 


\section{Research methodology}

Data was gathered with the help of primary data and has been collected through pre-structured questionnaires based on Likert scale. Data has been obtained through questionnaires asked with respondents having experience of service quality of Bajaj two wheelers in Nepal and their satisfaction level at Kathmandu Valley. The whole owners of Bajaj two wheelers users are considered as the population of this study. The sample of the respondents used in this study constitutes 200 Bajaj motorcycle users at Kathmandu Valley. This sample size derived accurate insights of this study to meet the objectives of the study. There are also some bound to survey the large population i.e. budget, time frame etc. Statistical tools like correlation have been done using SPSS software to measure the service quality and customer satisfaction of two wheelers in Nepal.

\section{Result and Discussion}

In the course of analysis, data collected through questionnaire has been presented in tabular forms:

\section{Purpose of using motorbike}

The sample respondents were asked about the purpose of motorbike they used. The response from sample respondents is presented in Table 1.

Table 1: Purpose of using motorbike

\begin{tabular}{|c|c|c|}
\hline Purpose & Frequency & Percent \\
\hline Business & 35 & 17.5 \\
\hline Personal & 113 & 56.5 \\
\hline Both & 52 & 26 \\
\hline Total & 200 & 100 \\
\hline
\end{tabular}

(Source: Field Survey, 2019)

Table 1 indicates that the majority of respondents use the Bajaj motorbike for their personal use i.e. 56.5 percent while 17.5 percent use Bajaj motorbike for their business use. And 26 percent of sample respondents use the Bajaj motorbike for their personal and business use. It indicates that the majority of sample respondents use their Bajaj motorbike as their personal use only.

\section{Duration of using Bajaj motorbike}

The sample respondents were asked about the duration of Bajaj motorbike they used. The response from sample respondents is presented in Table 2.

Table 2: Duration of using Bajaj motorbike

\begin{tabular}{|l|l|l|}
\hline Duration & Frequency & Percent \\
\hline Less than 1 Year & 49 & 24.5 \\
\hline 1-3 Years & 97 & 48.5 \\
\hline 3-5 Years & 33 & 16.5 \\
\hline Over 5 Years & 21 & 10.5 \\
\hline Total & 200 & 100 \\
\hline
\end{tabular}

(Source: Field Survey, 2019) 
Table 2 depict that the majority of sample respondents use the Bajaj motorbike for one to three years i.e. $48.5 \%$ while $24.5 \%$ respondents use Bajaj motorbike less than one year. Similarly $16.5 \%$ respondents use their motorbike for three to five years while $10.5 \%$ use their Bajaj motorbike for more than five years. Majority of sample respondents use new Bajaj motorbike while only few numbers of respondents use old Bajaj motorbikes.

\section{Satisfaction of usage of Bajaj motorbike}

The sample respondents were asked about the service and their satisfaction of usage of Bajaj motorbike. The respondents were asked to rate the satisfaction level on Likert scale i.e. 'strongly dissatisfied' to 'strongly satisfied' in five points. The rating from sample respondents on their satisfaction level is presented in Table 3.

Table 3: Satisfaction of using Bajaj motorbike

\begin{tabular}{c|c|c}
\hline Satisfaction & Frequency & Percent \\
\hline Strongly Dissatisfied & 15 & 7.5 \\
\hline Dissatisfied & 27 & 13.5 \\
\hline Neutral & 18 & 9 \\
\hline Satisfied & 109 & 54.5 \\
\hline Strongly Satisfied & 31 & 15.5 \\
\hline Total & $\mathbf{2 0 0}$ & $\mathbf{1 0 0}$ \\
\hline
\end{tabular}

(Source: Field Survey, 2019)

Table 3 presents the satisfaction of sample respondents for using Bajaj motorbike. Majority of sample respondents was satisfied with the service quality of the Bajaj motorbike. 54.5\% sample respondents were satisfied with the service quality of Bajaj motorbike while $15.5 \%$ was strongly satisfied. $9 \%$ respondents were either satisfied or dissatisfied while $13.5 \%$ respondents were dissatisfied with the service quality of Bajaj motorbike. Only 7.5\% respondents were strongly dissatisfied with the service quality of Bajaj motorbike. The data show that the there were more loyal customers of Bajaj motorbike.

\section{Correlation matrix between service quality dimension and customer satisfaction}

A correlation matrix is a table showing correlation coefficients between variables. Each cell in the table shows the correlation between two variables. A correlation matrix is used to summarize data, as an input into a more advanced analysis, and as a diagnostic for advanced analyses. A correlation matrix is simply a table which displays the correlation coefficients for different variables. The matrix depicts the correlation between all the possible pairs of values in a table. It is a powerful tool to summarize a large data set and to identify and visualize patterns in the given data. A correlation matrix consists of rows and columns that show the variables. Each cell in a table contains the correlation coefficient. Table 4 shows the correlation between the dependent variable and independent variable which was used under the study. Customer satisfaction is a dependent variable and responsiveness, reliability, assurance, tangibility and empathy the service quality dimension are independent variables. The Table 4 examines how perfectly correlated a service quality dimension is with customer satisfaction under the study. 
Table 4: Correlation matrix

\begin{tabular}{|c|c|c|c|c|c|c|c|}
\hline & & $\begin{array}{l}\text { Satisfac- } \\
\text { tion }\end{array}$ & $\begin{array}{l}\text { Respon- } \\
\text { siveness }\end{array}$ & $\begin{array}{l}\text { Reliabil- } \\
\text { ity }\end{array}$ & \begin{tabular}{|l} 
Assur- \\
ance
\end{tabular} & \begin{tabular}{|l} 
Tangi- \\
bility
\end{tabular} & \begin{tabular}{|l} 
Empa- \\
thy
\end{tabular} \\
\hline \multirow[t]{3}{*}{ Satisfaction } & Pearson Correlation & 1 & - & - & - & - & - \\
\hline & Sig. (2-tailed) & &.- & - & - & - & - \\
\hline & $\mathrm{N}$ & 200 & - & - & - & - & - \\
\hline \multirow[t]{3}{*}{ Responsiveness } & Pearson Correlation & .498 & 1 & - & - & - & - \\
\hline & Sig. (2-tailed) & .000 & & - & - & - & - \\
\hline & $\mathrm{N}$ & 200 & 200 & - & - & - & - \\
\hline \multirow[t]{3}{*}{ Reliability } & Pearson Correlation & .557 & .907 & 1 & - & - & - \\
\hline & Sig. (2-tailed) & .000 & .000 & & - & - & - \\
\hline & $\mathrm{N}$ & 200 & 200 & 200 & - & - & - \\
\hline \multirow[t]{3}{*}{ Assurance } & Pearson Correlation & $.519^{* *}$ & .958 & $.899^{* *}$ & 1 & - & - \\
\hline & Sig. (2-tailed) & .000 & .000 & .000 & & - & - \\
\hline & $\mathrm{N}$ & 100 & 200 & 200 & 200 & - & - \\
\hline \multirow[t]{3}{*}{ Tangibility } & Pearson Correlation & .482 & $.945^{*}$ & .894 & .938 & 1 & - \\
\hline & Sig. (2-tailed) & .000 & .000 & .000 & .000 & & - \\
\hline & $\mathrm{N}$ & 200 & 200 & 200 & 200 & 200 & - \\
\hline \multirow[t]{3}{*}{ Empathy } & Pearson Correlation & $.426^{*}$ & .884 & .854 & .889 & $.892^{*}$ & 1 \\
\hline & Sig. (2-tailed) & .000 & .000 & .000 & .000 & .000 & \\
\hline & $\mathbf{N}$ & 200 & 200 & 200 & 200 & 200 & 200 \\
\hline
\end{tabular}

(Source: SPSS Output)

Correlation is significant at the 0.01 level (2-tailed).

Table 4 shows the correlation relationship between customer satisfaction with different other service quality variables i.e. responsiveness, reliability, assurance, tangibility and empathy. The correlation between customer satisfaction and responsiveness was positively correlated (0.498) in positive direction which is moderate degree of correlation. Positive correlation coefficients indicate a direct relationship, indicating that as increasing responsiveness by Bajaj Company for Bajaj two wheelers the level of satisfied customer also increases. Similarly, the correlation between customer satisfaction and reliability is also positively correlate i.e. (0.557) which indicates that the increase in reliability a service quality dimension will increase customers satisfaction on Bajaj motorbikes. Correlation between customer satisfaction and assurance was positively correlate i.e. (0.519) which the result can consider as assurance and customer satisfaction are simultaneously, which means the Bajaj company increase the assurance service quality dimension, the satisfied customers also increased. Customer satisfaction and tangibility service quality dimension is moderately correlated (0.482) in positive direction. It means we should consider about tangibility service quality dimension and customer satisfaction simultaneously. Similarly, the service quality model empathy and customer satisfaction also have positive correlation i.e. (0.426) which shows the moderate association between empathy and customer satisfaction. 
The Sig. (2-Tailed) value in Table 4.11 for responsiveness, reliability, assurance, tangibility and empathy is 0 . This value is less than .05 . Because of this, we can conclude that there is a statistically significant correlation between customer satisfaction of Bajaj two wheelers and responsiveness, reliability, assurance, tangibility and empathy.

\section{Findings}

Majority of respondents use the Bajaj motorbike for their personal use i.e.56.5\% while $17.5 \%$ use Bajaj motorbike for their business use. And 26\% of sample respondents use the Bajaj motorbike for their personal and business use. $48 \%$ sample respondents use the Bajaj motorbike for one to three years while $24.5 \%$ respondents use Bajaj motorbike less than one year. Similarly, $16.5 \%$ respondents use their motorbike for three to five years while $10.5 \%$ use their Bajaj motorbike for more than five years. Majority of sample respondents use new Bajaj motorbike while only few numbers of respondents use old Bajaj motorbikes. Majority of sample respondents was satisfied with the service quality of the Bajaj motorbike. 54.5\% sample respondents were satisfied with the service quality of Bajaj motorbike while $7.5 \%$ was strongly satisfied. 9\% respondents were either satisfied or dissatisfied while $13.5 \%$ respondents were dissatisfied with the service quality of Bajaj motorbike. Only 7.5\% respondents were strongly dissatisfied with the service quality of Bajaj motorbike.

The correlation between dependent variable customer satisfaction and independent variables: responsiveness, assurance, reliability, tangibility and empathy were positively correlated (0.498), (0.557), (0.519), (0.482) and (0.426) respectively in positive direction which has moderate degree of correlation. Positive correlation coefficients indicate a direct relationship, indicating that as increasing responsiveness, assurance, reliability, tangibility and empathy service quality dimensions by Bajaj company for Bajaj two wheelers the level of satisfied customer also increases.

\section{Conclusion}

This research resulted in the development of a valid and reliable scale for measuring service quality in the Bajaj two wheelers in Nepal. The literature review concluded that despite of wide acceptance of the American perspective of service quality proposed by Parasuraman et al. (1988), service quality measurement must be adapted to fit the context as there is no universal set of dimensions and items that determine the service quality across a section of industries and cultures. The findings of this research confirm this conclusion as the service quality measurement scale developed in this research has five service quality dimensions and all dimensions emerge as a significant dimension in the scale developed in this study.

This research should be seen as a preliminary attempt at addressing an issue that has important implications for service quality and customer satisfaction. Any preliminary attempt will involve a number of limitations. However, acknowledgement of these limitations suggests new directions for future studies. 


\section{References}

Adusei, C. \& Koduah, T. (2019). After-Sales Service and Customer Satisfaction in the Automobile Industry in an Emerging Economy. Open Access Library Journal, 1(60), 44-59.

Ambekar, S.S. (2017). Service Quality Gap Analysis of Automobile Service Centers. Indian Journal of Research in Management, Business and Social Sciences (IJRMBSS), 1 (1), 5-6.

Brady, M. \& Cronin, J. (2001). Some New Thoughts on Conceptualizing Perceived Service Quality: A Hierarchical Approach. Journal of Marketing, 3 (65), 34-49.

Bruner, G. C., Hansel, P. J., \& James, K. E. (2001). Marketing Scales Handbook.(5 ${ }^{\text {th }}$ ed.) Chicago, IL: American Marketing Association.

Burns, A. C. \& Bush, R. F. (1985). Marketing Research. (8 ${ }^{\text {th }}$ ed.). Englewood Cliffs, New Jersey, USA: Prentice-Hall.

Gronroos, C. (2007.) In Search of a New Logic for Marketing: Foundations of Contemporary Theory. New Delhi:West Sussex John Wiley and Sons Ltd.

Khan, M.A. \& Rao, V.M. (2018). Two Wheelers Consumer Behaviours Towards Customer Satisfaction. International Journal of Research Granthalaya, 6 (2), 511-513.

Khan, M.T. \& Jadoun, R.S. (2015). Evaluation of Service Quality in Two-Wheeler Automobile Industries Using Servqual Model. International Journal of Innovative Research in Science, Engineering and Technology, 4 (5), 21-24.

Khanal,R.P.(2016). Analysis of Service Quality and Increasing Automobile Market and its Impact. Kathmandu: An Unpublished Master's Degree Thesis, Submitted to Office of the Dean, Faculty of Management,T.U.

Kotler, P. \& Armstrong, G. (2010). Principles of Marketing. 13th edn. London: Pearson.

Oliver, R.L. (1996). Satisfaction: A Behavioral Perspective on the Consumer. New York: McGraw- Hill.

Palmer, A. (2008). Principles of Service Marketing. 5th edn. London: The McGraw- Hill Companies.

Parasuraman, A., Zeithaml, V. A., \& Berry, L. L. (1988). SERVQUAL: A Multiple- Item Scale for Measuring Consumer Perceptions of Service Quality. Journal of Retailing, 64 (1),12-40.

Poudel. S. (2015). Customer Satisfaction in Automobile Industry. Kathmandu: An Unpublished Master's Degree Thesis, Submitted to Office of the Dean, Faculty of Management, T.U.

Rimal, A. (2018). A Study on Two Wheelers Consumers Behaviour and Consumer Satisfaction. Kathmandu: An Unpublished Master's Degree Thesis, Submitted to Office of the Dean, Faculty of Management, T.U.

Schiffman, L. G. \& Kanuk, L. (2004) Consumer Behaviour. 8th edition. New Jersey: Pearson Education Inc, Upper Saddle River Titus.

Solomon, M.R. (2009). Consumer behaviour, Buying, Having and Being. $8^{\text {th }}$ edition. New Delhi: Pearson Education, Inc.

Wilson, A., Zeithaml, V.A., Bitner M.J., \& Gremler, D.D. (2008). Services Marketing. NewYork: McGraw Hill Education.

Zeithaml, V. A., Bitner, M. J., \& Gremler, D. D. (2006). Services Marketing (4th ed.). New-Delhi: McGraw Hill Publication.

Zeithaml, V. A., Bitner, M. J., \& Gremler, D. D. (2009). Services Marketing. 5th edition. McGraw-Hill. 